\title{
The CAG Research Committee report: Investment in excellence
}

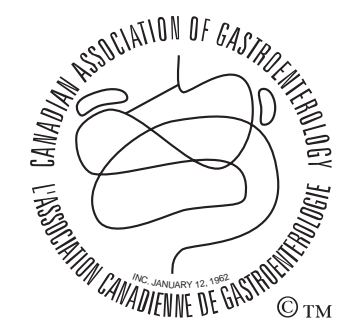

En français voir page 569

Derek M McKay PhD

Chair, CAG Research Committee

$\mathrm{I}^{\mathrm{n}}$

nvestment in research is a cornerstone of the Canadian Association of Gastroenterology (CAG). It was a singular honour to succeed Dr Wallace K MacNaughton (University of Calgary, Alberta) as the chair of the CAG Research Committee in February 2002. During his term (2000 to 2002), Dr MacNaughton did an outstanding job for the Association, and I will strive to meet the high standards that he and his predecessors set. It is a pleasure to have this opportunity to thank Wally for his tireless efforts as the past chair of the Research Committee.

The present article briefly outlines the activities of the Research Committee during the 2001 to 2002 academic year. But first, I will gratefully acknowledge the efforts of the entire Research Committee (Table 1) and Mr Paul Sinclair, the CAG National Executive Director, for their active participation in and commitment to the research activities of the CAG. Thank you.

\section{TRAINING PROGRAMS}

The fellowship awards are the flagship program of the CAG Research Committee and will continue to be so. Investment in talented young basic and clinical scientists is crucial if Canada is to stay at the forefront of gastroenterological research. Based on successful and continued support from our industrial partners, the Crohn's and Colitis Foundation of Canada (CCFC) and the Canadian Institutes of Health Research (CIHR), we were able to fund $17 \mathrm{fel}$ lowships, effective July 1, 2002 (Table 2) - this represents a

\section{TABLE 1}

Current members of the Canadian Association of Gastroenterology Research Committee

\begin{tabular}{lll}
\hline Member & Institution & Term \\
\hline Derek M McKay PhD (Chair) & McMaster University, Hamilton, Ontario & $2002-2005$ \\
David Armstrong MA MB BChir FRCPUK FRCPC & McMaster University, Hamilton, Ontario & $2002-2005$ \\
Marc Deschenes MD FRCPC & McGill University, Montreal, Quebec & $2002-2005$ \\
William Paterson MD FRCPC & Queen's University, Kingston, Ontario & $2001-2004$ \\
Johane Allard MD FRCPC & University of Toronto, Ontario & $2001-2004$ \\
Jean-Francois Beaulieu PhD & Sherbrooke University, Quebec \\
Herbert Gaisano MD FRCPC FACP & University of Toronto, Ontario & $2001-2004$ \\
Alison Buchan PhD & University of British Columbia, Vancouver \\
Kris Chadee PhD & McGill University, Montreal, Quebec \\
Stephen Vanner* MD FRCPC MSc & Queen's University, Kingston, Ontario & $2000-2003$ \\
\hline
\end{tabular}

${ }^{\star}$ Representative of the Canadian Digestive Health Foundation

The CAG is proud to acknowledge its Benefactor Corporate Sponsors:
Abbott Laboratories Ltd.
AstraZeneca Canada Inc.
Axcan Pharma Inc.
Janssen-Ortho Inc. 
TABLE 2

Industrial partner/Canadian Institutes of Health Research/Canadian Association of Gastroenterology fellowships funded in 2002

\begin{tabular}{|c|c|c|c|c|}
\hline Candidate & Industrial partner & Term (years) & Institution & Supervisor \\
\hline M Cantor & Abbott Laboratories Ltd & 1 & University of Manitoba, Winnipeg & C Bernstein \\
\hline M Akhtar & AstraZeneca Canada Inc & $2(+1)$ & McMaster University, Hamilton, Ontario & D McKay \\
\hline M Beyak & AstraZeneca Canada Inc & $2(+1)$ & Queen's University, Kingston, Ontario & S Vanner \\
\hline Y Motomura & AstraZeneca Canada Inc & $2(+1)$ & McMaster University, Hamilton, Ontario & S Collins \\
\hline L Yu & AstraZeneca Canada Inc & $2(+1)$ & University of Calgary, Alberta & A Buret \\
\hline P-Y Zheng & AstraZeneca Canada Inc & $2(+1)$ & University of Toronto, Ontario & N Jones \\
\hline K Scott & Axcan Pharma Inc & 2 & University of Virginia, Charlottesville & P Ernst \\
\hline M Silva & Axcan Pharma Inc & 2 & St Justine Hospital, Montreal, Quebec & E Seidman \\
\hline S Lebel & Byk Canada Inc & 2 & University of Toronto, Ontario & $\mathrm{N}$ Jones \\
\hline C Bonder & $\begin{array}{l}\text { Crohn's and Colitis Foundation } \\
\text { of Canada }\end{array}$ & $1(+1)$ & University of Calgary, Alberta & $\begin{array}{c}\text { P Kubes } \\
\text { D-M McCafferty }\end{array}$ \\
\hline S Ganguli & $\begin{array}{l}\text { Crohn's and Colitis Foundation } \\
\text { of Canada }\end{array}$ & 1 & McMaster University, Hamilton, Ontario & G Tougas \\
\hline M Ferazzini & Ferring Pharmaceuticals & 1 & University of Calgary, Alberta & N Vergnolle \\
\hline M Ropeleski & $\begin{array}{l}\text { Novartis Pharmaceuticals } \\
\text { Canada Inc }\end{array}$ & 1 & University of Chicago, Illinois & E Chang \\
\hline N Zarate & $\begin{array}{l}\text { Novartis Pharmaceuticals } \\
\text { Canada Inc }\end{array}$ & 1 & McMaster University, Hamilton, Ontario & $\begin{array}{l}\text { J Huizinga } \\
\text { G Tougas }\end{array}$ \\
\hline M Ajuebor & Schering Canada Inc & 1 & University of Calgary, Alberta & M Swain \\
\hline O Menezes de Lima & Solvay Pharma Inc & 2 & University of Calgary, Alberta & J Wallace \\
\hline I Tai & Solvay Pharma Inc & 2 & $\begin{array}{l}\text { Dana-Farber Cancer Institute, Boston } \\
\text { Massachusetts }\end{array}$ & LB Chen \\
\hline
\end{tabular}

TABLE 3

Crohn's and Colitis Foundation of Canada (CCFC) and Canadian Association of Gastroenterology (CAG) Summer Studentships (2002)

\begin{tabular}{llll}
\hline Candidate & Sponsor & Institution & Supervisor \\
\hline A Robinson & CCFC & University of Calgary, Alberta & WK MacNaughton \\
A Hayward & CCFC & Dalhousie University, Halifax, Nova Scotia & A Stadnyk \\
L Youden & CCFC & Dalhousie University, Halifax, Nova Scotia & A Stadnyk \\
A Bongard & CCFC & McMaster University, Hamilton, Ontario & SM Collins \\
V Ng & CAG & University of Toronto, Ontario & H Gaisano \\
L Meddings & CAG & University of Calgary, Alberta & K Sharkey \\
S Ansari & CAG & McMaster University, Hamilton, Ontario & DM McKay
\end{tabular}


one-year investment of approximately $\$ 1,020,000$ ! These awards are somewhat unique within the Canadian research arena, providing salary support for the fellows, some research operating funds and an allowance to permit fellows to present the data obtained during their fellowship at a national or international conference. The quality of the applications and the success rate $(65 \%)$ are a fitting testimony to the emphasis that the CAG places on supporting talented young scientists and augurs well for Canadian gastrointestinal research. In total, 25 applications were reviewed in this competition.

Furthermore, it is particularly gratifying to report that successful applications were obtained from fellows to work in the laboratories of Dr N Jones (Assistant Professor, University of Toronto, Ontario) and Dr N Vergnolle (Assistant Professor, University of Calgary, Alberta), previous recipients of CAG fellowships themselves.

It is equally pleasing to be able to support more junior researchers, with the aims of stimulating their interest in research and attracting them to the study of enteric health and disease. By the time this newsletter comes to press, seven undergraduate students will be actively employed in research laboratories across Canada, their research being made possible by the summer studentship program that is funded by the CAG and the CCFC (Table 3). Eleven applications were reviewed in this competition.

\section{GRANTS}

The CAG, in partnership with the Canadian Digestive Health Foundation (CDHF), gave out two operating grants effective July 1, 2002. The new investigator grant was awarded to Dr Joseph Romagnuolo at the Foothills Medical Centre (University of Calgary, Alberta) to initiate a project entitled "Allopurinol for the prevention of ERCP-related pancreatitis: a placebo-controlled randomized trial". This grant is partnered with Byk Canada Inc. The second award went to Dr Carole Creuzenet from the University of Western Ontario, London, for her project "Functional and clinical investigation of two new genes involved in the control of the virulence of Helicobacter pylori" (industrial partner: Abbott Laboratories Ltd).

Congratulations are extended to all the successful fellows, summer students and grant awardees. We look forward to your continued participation in Canadian gastrointestinal research and the results of your labours in the years to come. Well done!

\section{CANADIAN DIGESTIVE DISEASES WEEK 2002}

The Canadian Digestive Diseases Week (CDDW) is the showcase for the efforts of the gastrointestinal research community. In the July 2002 issue of The Canadian Journal of Gastroenterology (1), we outlined the themes for the 2003 event. Here, I summarize the highlights of CDDW 2002. Approximately 200 abstracts were submitted to the scientific program, and over $95 \%$ of these were accepted for presentation - 12 as oral presentations and the remainder as posters, presented over the three days of the scientific meet- ing. Scientific symposia focused on the epithelial barrier in health and disease; chemokines and their non-chemotactic functions; and the role of NOD in Crohn's disease. The following people were presented with CAG awards for 2002 at the meeting.

\author{
Dr Jan Huizinga \\ (McMaster University, Hamilton, Ontario) \\ Research Excellence Award \\ Dr Wallace MacNaughton \\ (University of Calgary, Alberta) \\ Young Investigator Award \\ Dr Richard Fedorak \\ (University of Alberta, Edmonton) \\ Visiting Professor Award \\ Dr Richard Hunt \\ (McMaster University, Hamilton, Ontario) \\ Distinguished Service Award \\ Dr Eldon Shaffer \\ (University of Calgary, Alberta) \\ Distinguished Service Award \\ Prof Joseph Sung \\ (Hong Kong University) \\ The RD McKenna Memorial Lecture \\ Dr Jack Gauldie \\ (McMaster University, Hamilton, Ontario) \\ State of the Art Lecture
}

Student prizes for the outstanding quality of their abstracts were awarded to Ms K Howe (McMaster University, Hamilton, Ontario), Ms Pengfei Zhou (McMaster University, Hamilton, Ontario), Mr JL Watson (McMaster University, Hamilton, Ontario) and Mr J Riff (University of Toronto, Ontario). The student awards were sponsored by the CAG and the CCFC, with Mr Michael Howorth, the National Executive Director of the CCFC, presenting two of the awards at the awards ceremony.

As a new initiative, the CAG elected to provide partial support for workshops at scientific meetings. The funds $(\$ 5,000)$ are specifically allotted for CAG trainees to attend the meeting, because it is important that our trainees have the opportunity to interact with internationally renowned experts in gastroenterological research and present their work to as wide an audience as possible. In 2002, three meetings have been or will be supported: "The Enteric Nervous System" (organizer Dr K Sharkey); "Mechanisms of Tissue Damage and Repair in the GI Tract" (organizer Dr S Crowe); "Selected Topics in GI Disease" (November 2002, Hockley Valley Resort, Orangeville, Ontario; organizer Dr G Greenberg). We have committed support for one meeting in 2003: "Banff Inflammation Workshop" (February 2003; organizer Dr J Wallace). Details surrounding each of these meetings can be found on the CAG Web site at www.cag-acg.org. 


\section{DIRECTIONS}

As the new chair of the Research Committee (2002 to 2005), my primary goals are to foster and enhance both the quality and the quantity of all facets of research relating to gastrointestinal health and disease, ranging from the minutiae of intracellular signalling systems to whole animal and clinical observations. This can only be achieved by cooperative interaction with and the continued support of our pharmaceutical industrial partners, the CIHR, the CCFC and the CDHF. The research committee and I will strive to maintain the level of excellence that already exists in our funding programs and will work to develop new programs, which will, for example, ease the transition of our best fellows into faculty positions, stimulate interactions between the gastrointestinal community and other disciplines, and provoke active research interactions between different research institutes across the country.
Should any of the CAG membership have questions relating to the activities of the research committee or ideas on how to expand our research program, please feel free to contact either myself or any of the Research Committee members (Table 1).

ACKNOWLEDGEMENTS: Funding from the following is gratefully acknowledged: Abbott Laboratories Ltd, AstraZeneca Canada Inc, Axcan Pharma Inc, Byk Canada Inc, Ferring Pharmaceuticals, Novartis Pharmaceuticals Canada Inc, Schering Canada Inc, Solvay Pharma Inc, CCFC, CDHF and CIHR.

\section{REFERENCE}

1. Leddin DJ. Planning for Canadian Digestive Disease Week 2003. Can J Gastroenterol 2002;16:491-2. 


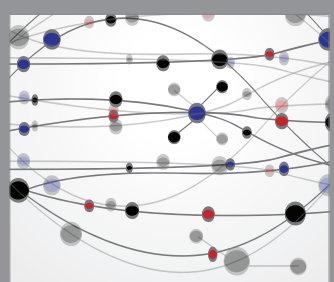

The Scientific World Journal
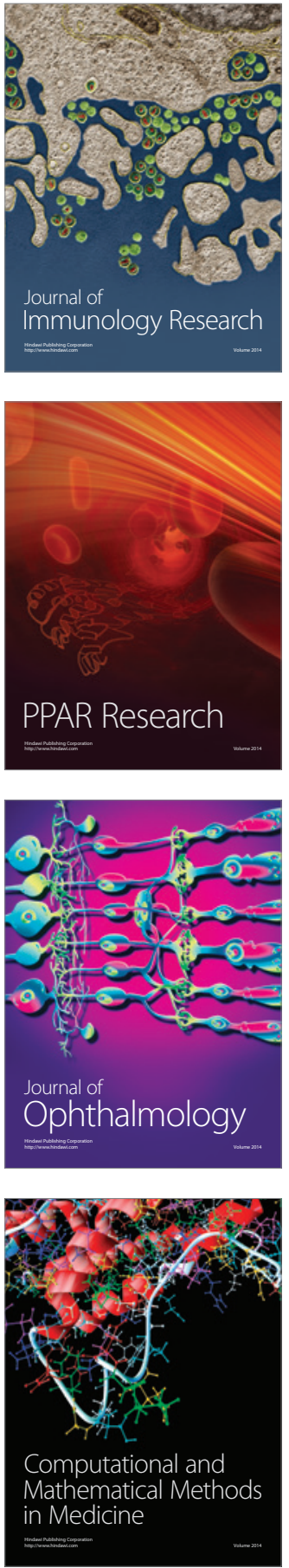

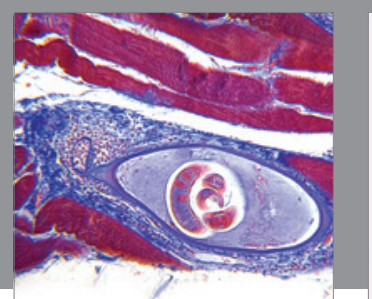

Gastroenterology Research and Practice

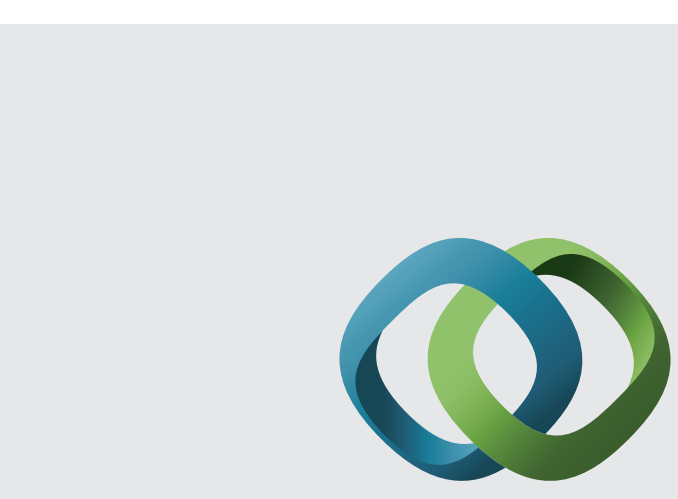

\section{Hindawi}

Submit your manuscripts at

http://www.hindawi.com
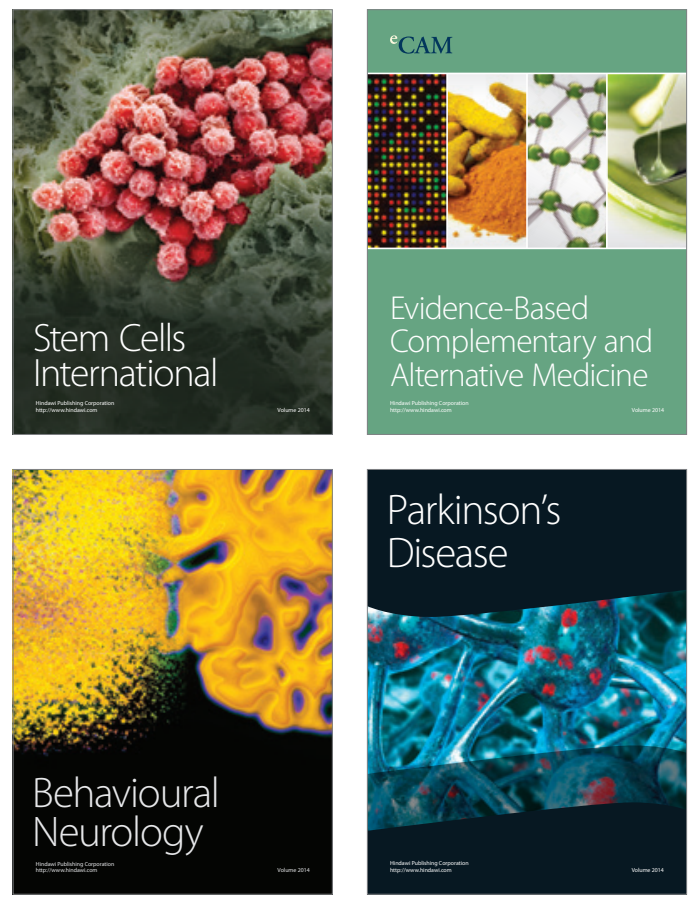
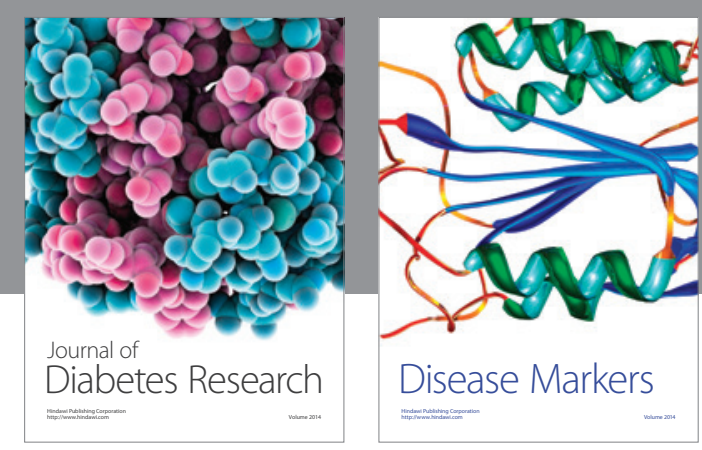

Disease Markers
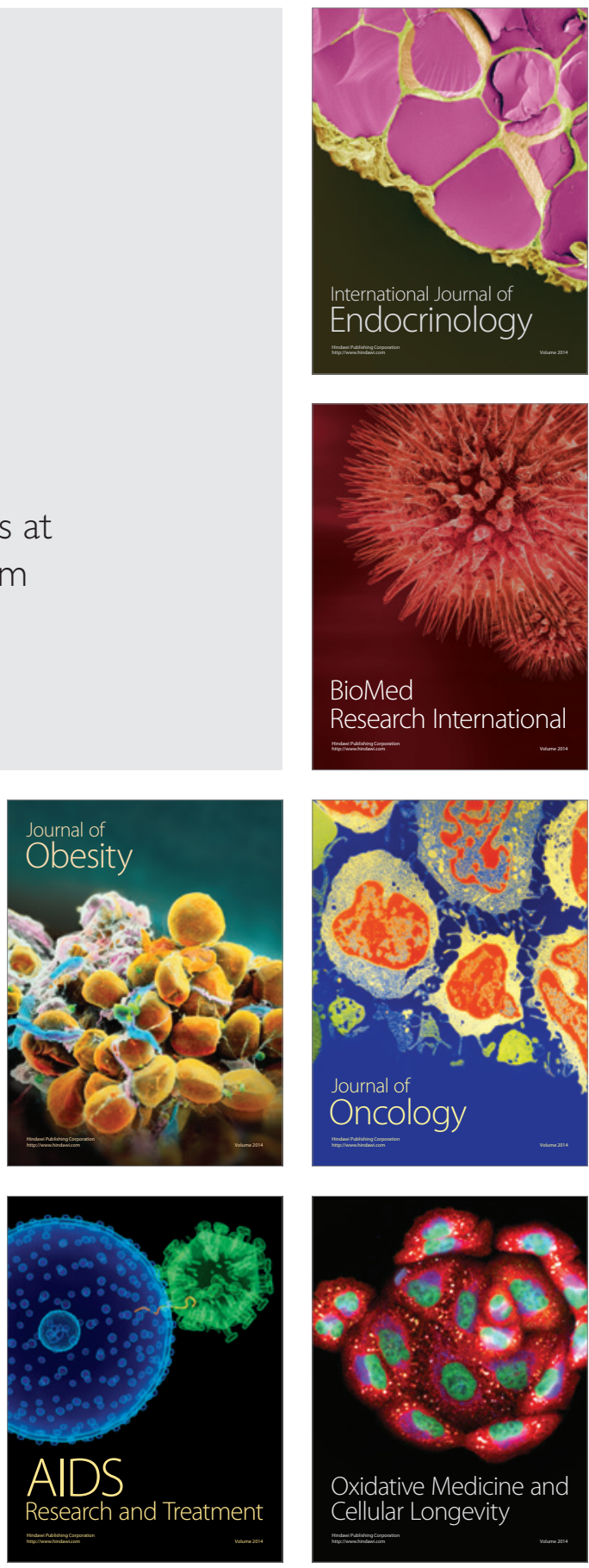